\section{Congress on Dog Breeding}

AN event of considerable interest to geneticists, psychologists, and especially to dog fanciers, is to take place at Frankfort on Main on April 22-25, when the Fédération Cynologique Internationale (F.C.I.) is to hold its third congress, which will be followed (April 26-28) by a dog show, open to all the world, and providing classes for all the known breeds. Discussion at the congress will deal mainly with the inheritance of the physical and mental characters of the dog, and papers will be presented by Prof. Henseler, of the Institüt für Tierzucht und Züchtungsbiologie in Munich; Prof. Pirocei, of Milan; Dr. Méry, of Paris ; and Major Most, of Berlin. Particulars concerning membership and programmes may be obtained from Fr. Bazille, Rotenwaldstr. $83 \mathrm{a}$, Stuttgart-W.

\section{Holly Lodge Farm}

According to The Times of February 6 the Conservative Parliamentary Agricultural Committee on February 5 unanimously adopted the following resolution: "That in view of the authoritative opinions on the educational and research value of the Holly Lodge and Crown Farms, Walton-onThames, especially in view of the Government's policy for the greater home production of fruit, vegetables, and flowers to replace foreign imports, this Committee expresses the earnest hope that these farms will not be destroyed under the reservoir scheme of the Metropolitan Water Board."

\section{Announcements}

Prof. A. C. Seward, professor of botany in the University of Cambridge, has been elected president of the South-Eastern Union of Scientific Societies in succession to Prof. H. L. Hawkins. The annual congress will be held at Bournemouth on June 26-29.

Prof. A. L. Goodhart, professor of jurisprudence, Oxford; Sir Walter Moberly, chairman of the University Grants Committee; and Prof. G. P. Thomson, professor of physics, Imperial College of Science, have been elected members of the Athenæum Club under the provisions of Rule II of the Club, which empowers the annual election by the Committee of a certain number of persons of distinguished eminence in science, literature, the arts, or for public service.

ON February 18 in the Lecture Hall of Manson House, Portland Place, Col. MacArthur, late R.A.M.C., will be presented with the Chadwick Gold Medal and Prize of $£ 100$ which, under the scheme of the trust, may be awarded once in five years to the medical officer of the Navy, Army or Air Force who has most distinguished himself during that period in promoting the health of the men of the Service to which he belongs.

Sir Peter Chalmers Mrtchell, who has been a member of Council since 1900 and secretary since
1903 of the Zoological Society of London, retires from that office on April 29, 1935. It is therefore proposed to present to the Society a portrait in oils of Sir Peter, by Mr. William Nicholson. Fellows and friends of the Society are invited to send contributions to the Portrait Secretary, c/o F. W. Bond, Zoological Society of London, Regent's Park, N.W.8.

Ar the meeting of the Industrial Research Council, Irish Free State, on February 2, it was announced that Mr. Eugene Boyle has been appointed chemical engineer for research on waxes under Prof. J. Reilly in University College, Cork.

Ar the twenty-ninth annual meeting of the Botanical Society of America on December 27-29 in Pittsburgh, Pennsylvania, the following elections were made : President, Dr. Aven Nelson, University of Wyoming; Vice-President, Dr. K. M. Wiegand, Cornell University; Corresponding Members, Sir David Prain, lately director of the Royal Botanic Gardens, Kew ; Prof. G. Haberlandt, emeritus professor of botany, University of Berlin ; Prof. Alvar Palmgren, professor of botany, University of Helsingfors.

THe first (January) issue of the Traveller, the quarterly journal of the University Travel Guild, contains short accounts of excursions of scientific, historical, architectural, musical, etc., interest which are being arranged by the Guild in 1935. Tours of scientific interest include "Palestine of the Bible", under the leadership of Dr. E. W. G. Masterman; "Dalmatia - a Botanical Tour", under the leadership of Dr. W. B. Turrill ; and Roman France. Copies of the Traveller (price 4d., or including postage 6d.) and further particulars of the University Travel Guild can be obtained from its offices, 25 Cockspur Street, London, S.W.1.

Applications are invited for the following appointments, on or before the dates mentioned :-An inspector of mine beacons in the Department of Mines, Southern Rhodesia-The Official Secretary, Office of the High Commissioner for Southern Rhodesia, Crown House, Aldwych, London, W.C.2 (Feb. 16). A lecturer in botany and physics at the Cheltenham Technical.College-The Secretary (Feb. 18). A technical officer in the Admiralty Technical Pool-The Secretary to the Admiralty (C.E. Branch), Whitehall, London, S.W.I (Feb. 18). A lecturer in hygiene and public health in the Charing Cross Hospital Medical School, 62 Chandos Street, W.C.2 - The Dean (Feb. 20). An assistant inspector of guns (metallurgy) in the Metal and Steel Factory, Ishapore (Indian Ordnance Department)-The Secretary, Military Department, India Office, London, S.W.1 (Feb. 20). A general manager and engineer in the Electricity Department of the Metropolitan Borough of Battersea-The Town Clerk, Battersea Town Hall, London, S.W.11. An assistant chemist, a junior chemist, and a biologist on the staff of the Research Association of British Flour Millers--The Director of Research, Old London Road, St. Albans. 